\title{
Population structure of the chub mackerel (Scomber colias) in the North-east Atlantic inferred from otolith shape and body morphometrics
}

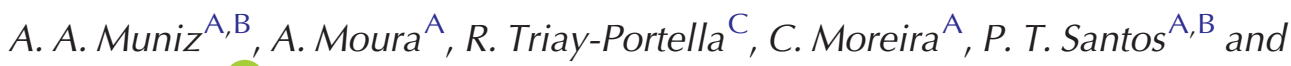 \\ A. T. Correia A, D,E \\ ${ }^{A}$ Centro Interdisciplinar de Investigação Marinha e Ambiental (CIIMAR/CIMAR), Terminal de \\ Cruzeiros do Porto de Leixões, Avenida General Norton de Matos S/N, 4450-208 Matosinhos, \\ Portugal. \\ ${ }^{B}$ Faculdade de Ciências da Universidade do Porto (FCUP), Rua Campo Alegre S/N, \\ 4169-007 Porto, Portugal. \\ CUniversidad de Las Palmas de Gran Canaria (ULPGC), Calle Juan de Quesada 30, \\ E-35001 Las Palmas de Gran Canaria, Las Palmas, Spain. \\ DFaculdade de Ciências da Saúde da Universidade Fernando Pessoa (FCS/UFP), \\ Rua Carlos Maia 296, 4200-150 Porto, Portugal. \\ ${ }^{\mathrm{E}}$ Corresponding author. Email: atcorreia.ciimar@gmail.com
}

\begin{abstract}
The Atlantic chub mackerel (Scomber colias) is an important commercial fish species of the North-east Atlantic. Two-year-old individuals collected between January and April of 2018 at six sampling locations (45 fish per site) of the North-east Atlantic (Azores, Madeira, Canaries and mainland Portugal - Matosinhos, Sesimbra and Portimão) were used for body morphometrics and otolith-shape analyses. Data were analysed by univariate and multivariate statistics. Re-classification success using shape analyses and body morphometrics showed an overall rate of 51 and 74\% respectively. Regional differences regarding the otolith-shape analyses suggested a single stock, not necessarily homogenous, with a discrete separation of two main groups (oceanic islands and mainland Portugal). However, body morphometrics showed a more detailed separation in two main groups (Canaries and the others, but with a slight differentiation between fish from Azores-Madeira and mainland Portugal). Moreover, joint analyses gave an overall re-classification success of $82 \%$ and allowed a more comprehensive scenario, showing the existence of three main groups (Canaries, Azores-Madeira and mainland Portugal). Regional differences are probably related with different oceanographic conditions influencing the feeding regime and fish growth. The hereby data suggest that S. colias caught in the North-east Atlantic are different population units, and we recommend a fishery management at a finer regional scale.
\end{abstract}

Additional keywords: fisheries, natural tags, Scombridae, stock delineation.

Received 18 December 2019, accepted 15 June 2020, published online 13 August 2020

\section{Introduction}

The Atlantic chub mackerel (Scomber colias) is a commercial and ecologically important fish species in the North-east Atlantic and Mediterranean Sea (Collette and Nauen 1983; Martins et al. 2013; Villamor et al. 2017). During the past years, the commercial landings in the Iberian Peninsula have increased significantly, in part, as a result of this species being target by the purse-seine fleets in Portugal and Spain (Villamor et al. 2017). In Portugal, $S$. colias is one of the most abundant species in the inshore waters and, over the past 15 years, landings have been increasing gradually, which could be related to its abundance, but also because it is being targeted to compensate for the low sardine (Sardina pilchardus) catches (Martins et al. 2013; Gamito et al. 2015). This species may represent an alternative to reduce the dependency of purse-seine fisheries on sardine stocks, and because of its low market cost, abundance and nutritional value, the Portuguese government is promoting a consumption campaign (European Commission 2017). In 2017, the total Portuguese landings were 19478 t, with the largest amount being landed in mainland Portugal (19090 t), followed by Madeira (195 t) and Azores (193 t). In mainland Portugal, different fishing gears are used for capturing this species, namely purse-seine nets (13756 t), multi-purpose fishing (5024 t) and trawling (310 t; DGRM 2018). 
Some regional studies were conducted on the reproductive biology, age, growth, feeding habits and life-history traits in mainland Portugal, Azores, Madeira and Canaries (Nespereira and Pajuelo 1993; Carvalho et al. 2002; Martins et al. 2007; Vasconcelos et al. 2012). The spawning season of $S$. colias varies among regions, extending over a period of 3-6 months: from March to August in Azores (Carvalho et al. 2002), from January to May in Madeira (Vasconcelos et al. 2012), and from February to June along the Portuguese coast (Martins et al. 2013). In Canaries, it takes place earlier, from November to February (Nespereira and Pajuelo 1993). This latitudinal gradient is related to seawater temperature, because spawning usually occurs when seawater is between $15^{\circ} \mathrm{C}$ and $20^{\circ} \mathrm{C}$ (Castro-Hernández and Santana-Ortega 2000). Surveys data suggest that recruitment occurs throughout the year, although mainly in the second half (ICES 2015). Acoustic abundance surveys suggest the existence of recruitment-nursery areas in Cantabrian Sea and Gulf of Cadiz (Villamor et al. 2017). However, information regarding the population structure, fish movement and connectivity patterns of this species is, at present, unknown.

The systematic state of $S$. colias could be controversial because of the existence of geographically distant populations with morphological variability and wide distribution pattern, encompassing the northern, southern, western and eastern Atlantic, as well as the Mediterranean Sea (Collette and Nauen 1983). Moreover, in the past the chub mackerel was usually described under the designation of $S$. japonicus, but later genetic studies have shown the existence of two distinct species, $S$. colias and $S$. japonicus, inhabiting in the Atlantic and Indo-Pacific oceans respectively (Scoles et al. 1998; Infante et al. 2007; Catanese et al. 2010). At present, existence of a single stock of $S$. colias in the Atlantic is considered on the basis of mtDNA analysis (Scoles et al. 1998). Furthermore, the observed extensive gene flow between populations of the North-east Atlantic Ocean and Mediterranean Sea, and the lack of regional structure found in $S$. colias, suggests the existence of a larger panmictic unit (Zardoya et al. 2004), which is consistent with one-stock management policy (Scoles et al. 1998). However, in the European Atlantic waters, available data about the spawning, recruitment and nursery grounds are still limited (ICES 2015). Despite being considered a 'Least Concern' species, there is some evidence of regional fishery declines, and local depletions should be monitored closely (IUCN 2011). Moreover, the Portuguese Institute for Sea and Atmosphere (IPMA) advised for the insufficient knowledge and lack of consistent data collection focussed on this species (Azevedo et al. 2012).

The use of continuous characteristics describing aspects of body shape is a common tool employed to study fish stocks (Erguden et al. 2009). Variation in such phenotypic characteristics is due to both environmental and genetic components (Cabral et al. 2003). Thus, regional morphometric-data variation is useful to discriminate fish-stock structure of various exploited marine fish species (Cabral et al. 2003; Erguden et al. 2009; Allaya et al. 2016), and can provide additional knowledge to a better management and conservation of fisheries (Erguden et al. 2009). Moreover, the otolith shape is also considered an efficient tool for fish-stock identification (Jemaa et al. 2015; Moreira et al. 2019a; Hoff et al. 2020) and has proven successful in resolving fish-stock structure in high gene-flow systems, when environmental heterogeneity exists (Bacha et al. 2014). Otolith shape is markedly species specific, but also shows intra-specific geographic variation in relation to environmental factors and fish growth (Ferguson et al. 2011; Jemaa et al. 2015; Moreira et al. 2019a). The combined use of both tools proved to be a useful methodology to study the population structure of marine fish (Vergara-Solana et al. 2013; Rodgveller et al. 2017; Vasconcelos et al. 2018).

The aim of this work was to apply, for the first time, body morphometrics and otolith-shape analyses to provide useful information on the population structure of $S$. colias among four main fishery grounds (Azores, Madeira, Canaries and mainland Portugal) in the North-east Atlantic, with implications for the fishery management.

\section{Materials and methods}

\section{Sample collection}

Fish samples were collected in Azores, Madeira, Canaries and mainland Portugal, namely Matosinhos, Sesimbra and Portimão (Fig. 1), from January to April 2018. Individuals $(20-27 \mathrm{~cm})$ were caught by purse seine and transported to the laboratory in isothermal containers with ice. The fish were measured (standard length (SL), $0.1 \mathrm{~cm}$ ), weighed $(W, 0.1 \mathrm{~g}$ ) and photographed with the landmarks for the body morphometric analyses (Erguden et al. 2009). Thereafter, sagittal otoliths were extracted with plastic forceps, cleaned of organic tissues with distilled water, air dried and stored in Eppendorf vials until further analysis (age estimates and otolith-shape analyses). Otolith pairs were distinguished according to the position of the sulcus acusticus and the rostrum (Secor et al. 1992), and the right sagittae were used for otolith-shape analyses. In total, 270 individuals of 2-years old (45 per location) were used for body morphometric and otolith-shape analyses (Table 1).

\section{Age estimates}

Sagittal otoliths were immersed in a clearing agent (ethanol and glycerol, $1: 1$ ) to enhance their transparency during age reading, with the distal surface turned up and the proximal surface (sulcus acusticus) turned down, and were examined using a stereomicroscope (EMZ-13TR, Meiji Techno, Japan) against a dark background with $\times 10$ magnification. Next, the age of each fish was assigned by counting the annual growth increments on sagittal otoliths according to an already existent standard protocol (ICES 2015). Ageing took into consideration the date of birth (1 January, following the rules in the northern hemisphere) and the date of capture (Panfili et al. 2002). Because the capture of the individuals occurred in the first semester, when a translucent ring was observed at the edge of the otolith, it was counted as an annulus (ICES 2015). Readings were performed by two independent and experienced readers, and only otoliths with $100 \%$ concordance were selected. Individuals of age-group 2 were selected from each region for further analyses. 


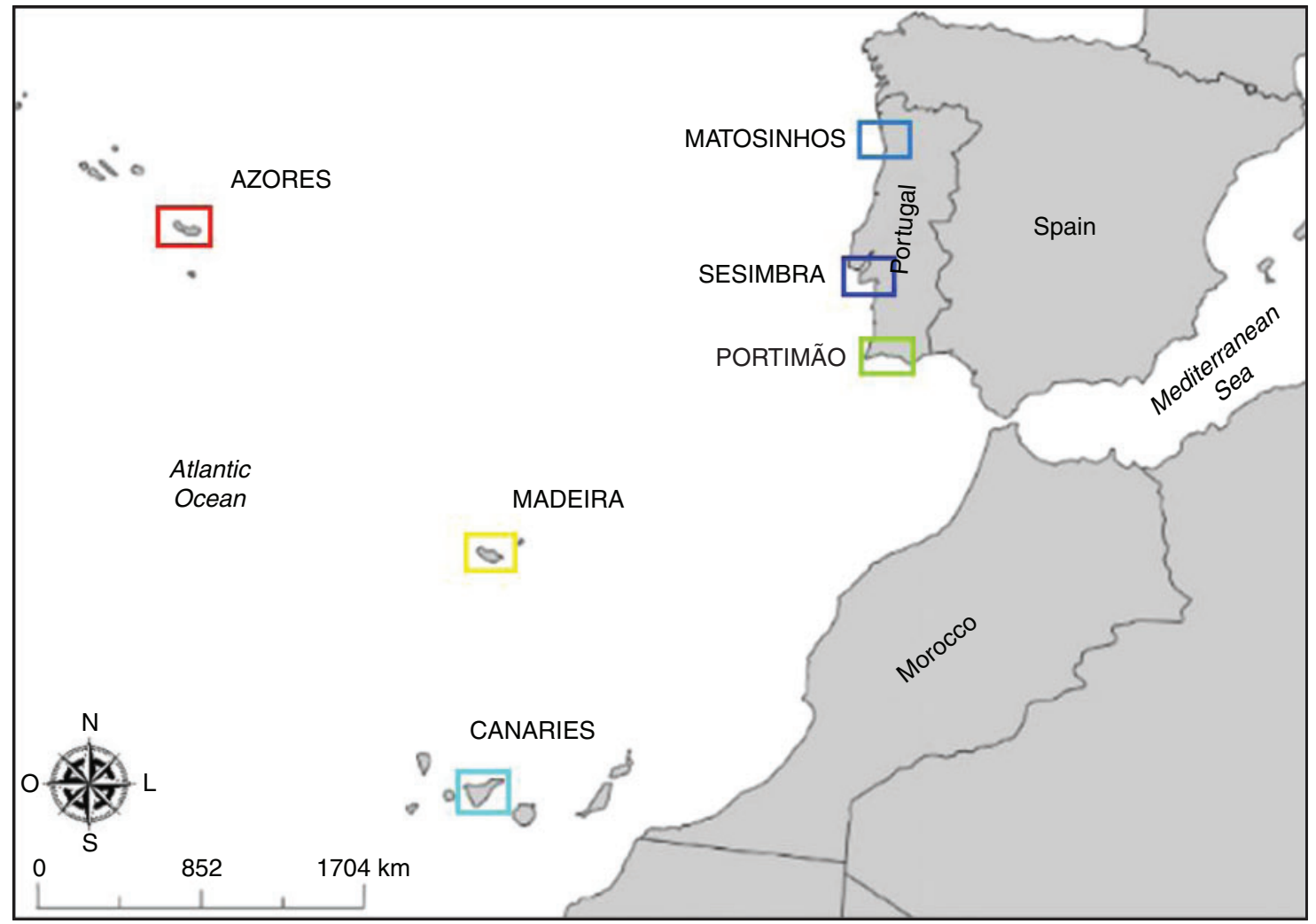

Fig. 1. Map showing the six sampling locations (Azores, Canaries, Madeira, Matosinhos, Sesimbra and Portimão) of Scomber colias caught in the North-east Atlantic from January to April 2018.

Table 1. Sampling location, sample size $(N)$, standard length (SL), body weight $(W)$ and otolith length (OL) of Scomber colias used for body-morphometric and otolith-shape analyses

Values are means \pm s.e.

\begin{tabular}{lllcrr}
\hline Region & Site & $N$ & SL $(\mathrm{cm})$ & $W(\mathrm{~g})$ & OL $(\mathrm{mm})$ \\
\hline Azores & - & 45 & $20.6 \pm 0.2$ & $128.4 \pm 3.8$ & $4.37 \pm 0.03$ \\
Canaries & - & 45 & $16.5 \pm 0.2$ & $84.7 \pm 1.9$ & $4.31 \pm 0.04$ \\
Madeira & - & 45 & $18.2 \pm 0.2$ & $87.1 \pm 1.8$ & $4.43 \pm 0.07$ \\
Mainland Portugal & Matosinhos & 45 & $20.1 \pm 0.2$ & $98.8 \pm 4.2$ & $4.15 \pm 0.04$ \\
& Portimão & 45 & $20.2 \pm 0.2$ & $93.7 \pm 2.2$ & $4.22 \pm 0.03$ \\
& Sesimbra & 45 & $19.2 \pm 0.2$ & $67.0 \pm 1.7$ & $3.97 \pm 0.05$ \\
\hline
\end{tabular}

\section{Otolith-shape analyses}

A digital image of each right otolith was taken by a stereomicroscope (EMZ-13TR, Meiji Techno, Japan) coupled with a USB digital camera (SC30, Olympus Corporation, Japan), using reflected light against a dark background. Otoliths were positioned with the sulcus acusticus up, and the rostrum pointed to the left (Fig. 2a). Care was taken to avoid the curvature of the otolith producing any deviation or error in the results (Volpedo and Vaz-dos-Santos 2015). The orthogonal two-dimensional pictures were, thereafter, transformed in black and white binary images (Fig. 2b) by using the free software Paintnet. Final images were processed using the free softwares ImageJ (shape indices, SIs, https://imagej.nih.gov/ij/download.html) and Shape Analysis ver. 1.3 (http://lbm.ab.a.u-tokyo.ac.jp/ iwata/shape/) (elliptic Fourier descriptors, EFDs).

Using the software ImageJ, size parameters such as otolith length $(\mathrm{OL}, \mathrm{mm})$, otolith width $(\mathrm{OW}, \mathrm{mm})$, otolith area $(\mathrm{OA}$, $\mathrm{mm}^{2}$ ) and otolith perimeter $(\mathrm{OP}, \mathrm{mm})$ were obtained. With these variables it was possible to calculate five SIs (Table 2), namely the form factor (FF), roundness (RO), ellipticity (EL), circularity (CI) and rectangularity (RE), according to Tuset et al. (2003).

The program Shape ver. 1.3 (Iwata and Ukai 2002) was used to extract the contour otolith shape (Fig. $2 c$ ) and to determine the number of EFDs required to adequately describe the otolith outline (Ferguson et al. 2011). The first six harmonics reached $>95 \%$ of the cumulative power (excluding coefficient D6), 
(a)

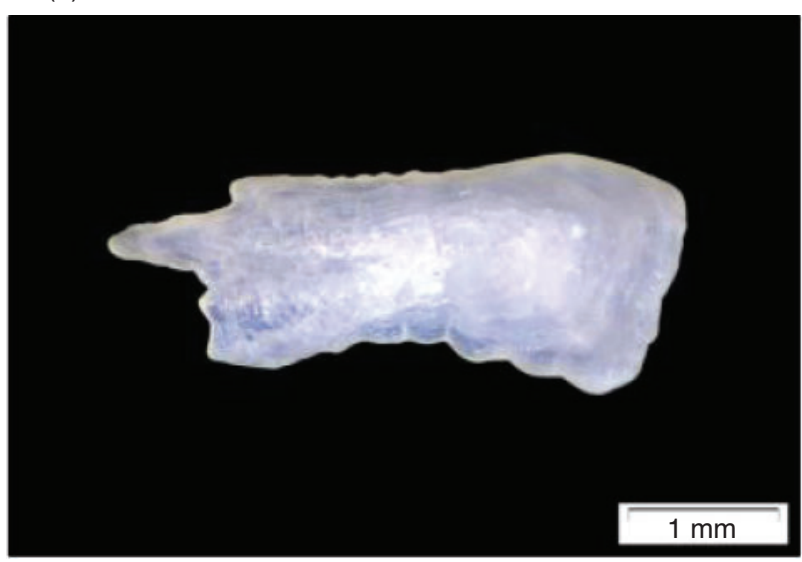

(b)

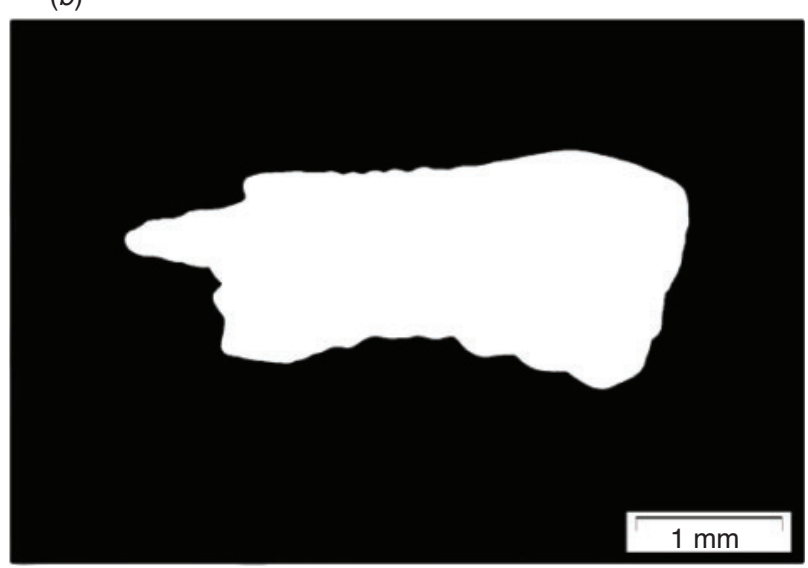

(c)

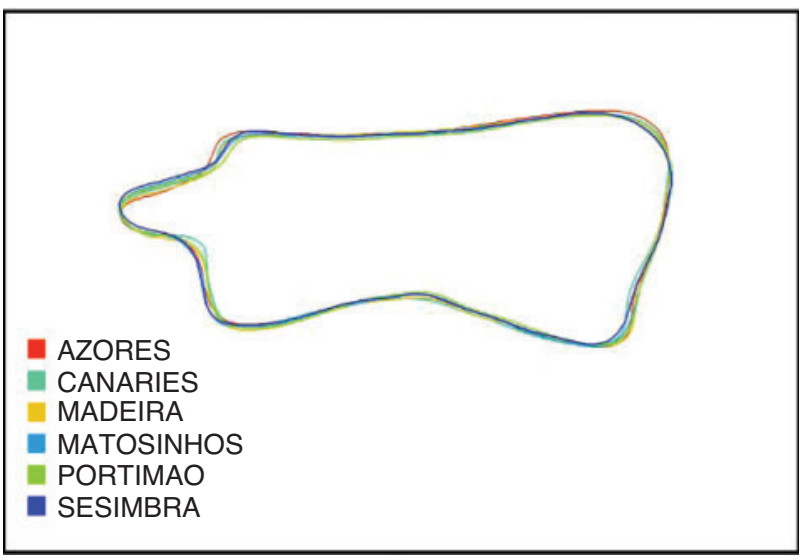

Fig. 2. Inner face of a right sagittae from Scomber colias, showing (a) the original photograph, $(b)$ the binary Black and White digital image, and (c) the otolith averaged outline contour for each location.

indicating that the otolith shape could be summarised by 23 Fourier coefficients, i.e. $6 \times 4-1=23$. Moreover, because the elliptical Fourier harmonics for each otolith were normalised to the first harmonic and were, thus, invariant to otolith size (Kuhl and Giardina 1982), the first three coefficients (A1, B1 and C1)
Table 2. Formulae used to obtain the five otolith-shape indices (SIs) from the size parameters otolith length $(\mathrm{OL}, \mathrm{mm})$, otolith width $(\mathrm{OW}, \mathrm{mm})$, otolith area $\left(\mathrm{OA}, \mathrm{mm}^{2}\right)$ and otolith perimeter $(\mathrm{OP}, \mathrm{mm}$; from Tuset et al. 2003)

\begin{tabular}{lc}
\hline Shape index (SI) & Formula \\
\hline Form factor (FF) & $(4 \pi \mathrm{OA}) / \mathrm{OP}^{2}$ \\
Roundness (RO) & $(4 \mathrm{OA}) /\left(\pi \mathrm{OL}^{2}\right)$ \\
Circularity (CI) & $\mathrm{OP}^{2} / \mathrm{OA}$ \\
Rectangularity (RE) & $\mathrm{OA} /(\mathrm{OL} \times \mathrm{OW})$ \\
Ellipticity (EL) & $(\mathrm{OL}-\mathrm{OW}) /(\mathrm{OL}+\mathrm{OW})$ \\
\hline
\end{tabular}

constant for all outlines were excluded, reducing the number of EFDs to 20 (i.e. $6 \times 4-1-3=20$ ).

\section{Body morphometrics}

For the analysis of the body morphometrics, a truss network system was used following a standard protocol (Strauss and Bookstein 1982). The left side of each fish, with the fins in the extended position, was photographed from a fixed distance with a high-quality digital camera (Fig. 3a). Only undamaged fish were included in the analyses. In total, 13 anatomical landmarks were defined along the body contour (Fig. $3 b$ ), determining 27 distances (DT; Table 3), on the basis of a previous morphometric study with this species (Erguden et al. 2009).

Landmarks were performed on digital images by using TpsUtil (ver. 1.76) and TpsDig (ver. 1.40) programs (available at https://life.bio.sunysb.edu/morph/). The user-friendly interface of the software allows the practitioner to precisely mark and record the $X-Y$ coordinates of the positions of each landmark to build the truss network. Vertices were estimated from $X$ and $Y$ coordinates of all specimens according to the least-square method (Rohlf and Slice 1990).

\section{Statistical analysis}

Raw data were checked for normality (Shapiro-Wilk test, $P>0.05$ ) and homogeneity of variances (Levene's test, $P>0.05)$. All assumptions were met after log 10 transformation (only CI).

Relationships between SI and OL (as covariate), and also between DT and SL (as covariate) were tested with analysis of covariance (ANCOVA). Location was treated as a fixed factor. All SI varied significantly with OL: EL and CI showed a positive relationship, whereas $\mathrm{FF}, \mathrm{RO}$ and $\mathrm{RE}$ showed a negative relationship (ANCOVAs, $P<0.05$ ). All variables were corrected using the ANCOVA slope, by using the formula Vadj $=$ $V-(\beta \times \mathrm{OL})$, where Vadj is the transformed value, $V$ is the original value, $\beta$ is the slope of the ANCOVA (Campana et al. 2000).

All DT showed a positive relationship with SL (ANCOVAs, $P<0.05)$. Size-dependent variation of morphometric characters was corrected to eliminate any variation resulting from allometric growth (Reist 1985), following the equation $M_{\text {transf }}=\log M_{-}$ $\beta(\log \mathrm{SL}-\log \mathrm{MSL})$, where $\mathrm{M}$ is the original morphometric measurement, $M_{\text {transf }}$ is the transformed morphometric measurement, $\beta$ is the slope of the regression of $\log M$ on $\log S L$, and SL is the standard length of fish, MSL is the overall mean of standard 
(a)

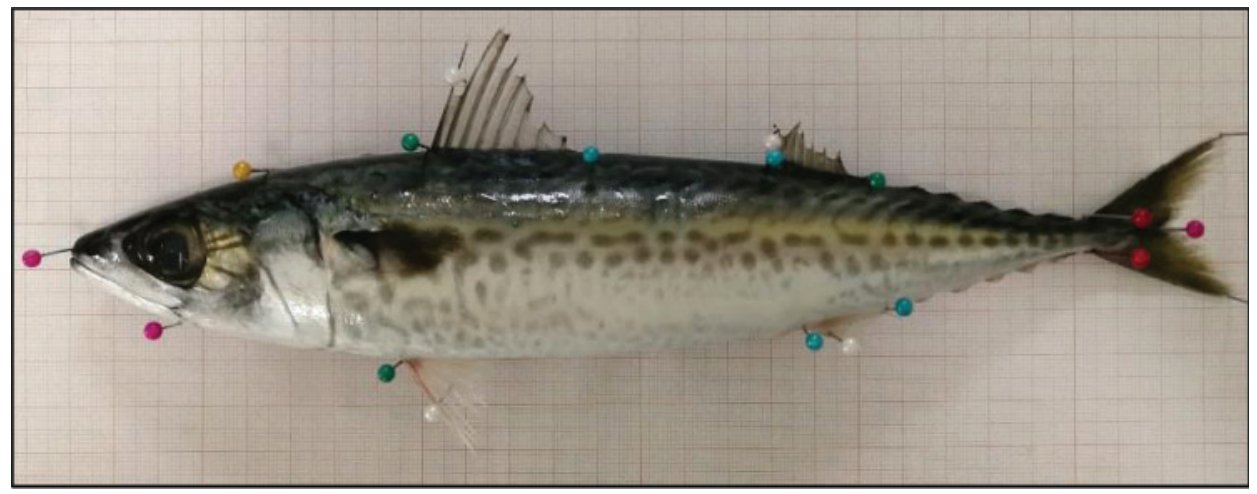

(b)

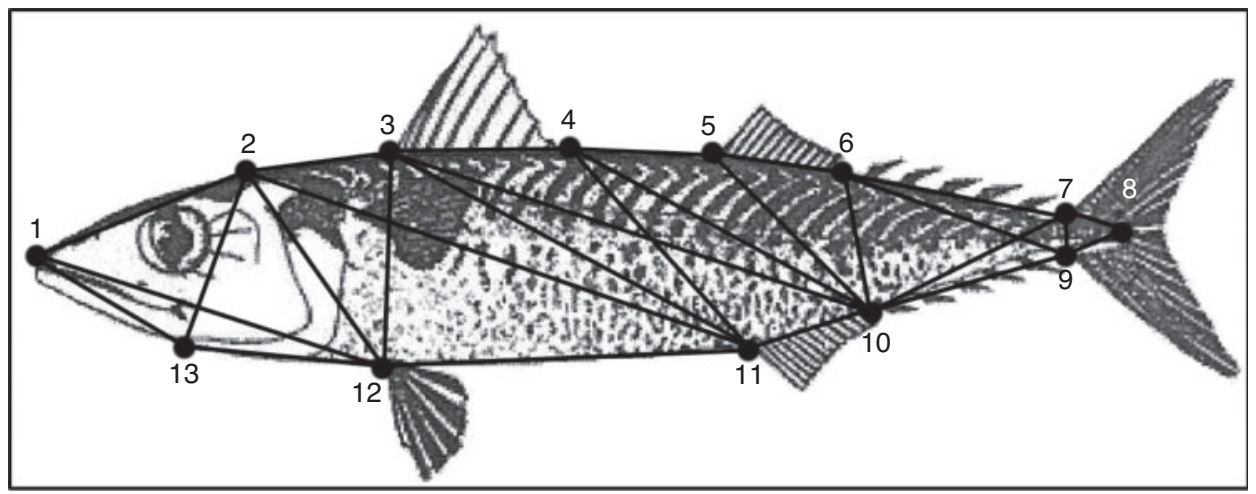

Fig. 3. Scomber colias (a) personal photograph from a specimen collected from Azores in February 2018, and (b) an illustration with the location of the 13 selected body landmarks (adapted from Collette 1986).

length for all fish from all samples for each variable (Kaouèche et al. 2017).

One-way ANOVA was used to explore the differences in otolith and body shape among the six locations, followed by a Tukey post hoc test, if needed $(P<0.05)$. A permutational multivariate variance of analysis (PERMANOVA) was used to compare the otolith and body shape among locations, and when statistically significant $(P<0.05)$, was followed by permutational pairwise comparisons (pseudo- $t$ statistic). A complete linear discriminant function analysis (LDFA), followed by a Jackknifed re-classification matrix (leave-one-out crossvalidation) was used to calculate the percentage of correctly re-classified specimens into the original location. A canonical analysis of principal coordinates (CAP) based on Euclidian distances was performed to identify the vectors of the components and their respective contributions. All statistical analyses were performed using the software Systat ver.12 (SysStat Software Inc., USA) and PRIMER (Quest Research Ltd, New Zealand) 6+PERMANOVA. Values are presented as means \pm standard errors (s.e.).

\section{Results}

Regarding the otolith-shape analyses, univariate tests showed significant differences among locations for almost all SIs and EFDs, with the exception of FF, CI, C2, B3, C4, D4 and A5 (oneway ANOVAs, d.f. $=5264, P>0.05$; Table 4$)$. RO, RE and EL, and all EFD showed differences among locations (one-way ANOVAs and Tukey post hoc tests, $P<0.05$ ). Multivariate analysis using all otolith-shape variables showed significant differences among regions (PERMANOVA: pseudo- $F=5.966$, d.f. $=5264, P<0.05)$. Moreover, all pairwise comparisons detected significant differences, with exception of Matosinhos and Sesimbra (pseudo-t-test, $P>0.05$ ). The jackknife matrix using the combination of both shape descriptors (SIs and EFDs) presented a low to moderate re-classification success of $51 \%$ (Table 5). The best classification rate was obtained for Canaries (73\%), followed by Matosinhos (58\%) and Azores (53\%). Individuals from Canaries were mis-classified mainly in Madeira and Azores; individuals from Matosinhos were misclassified mainly in Sesimbra and Portimão; and the individuals from Azores were mis-classified mainly in Canaries and Madeira. The lowest re-classification success was obtained for Sesimbra (29\%), in which the samples were more frequently mis-classified in Matosinhos followed by Portimão. The LDFA plot (Fig. 4a) showed a high overlap of individuals from all sampling locations for the SIs and EFDs combined. However, CAP allowed to slightly discriminate the following two main groups: one group with individuals from the Canaries, Azores and Madeira (Group 1), and another with individuals belonging to Matosinhos, Portimão and Sesimbra (Group 2). The vectors for RE, RO, A2, B5 and D2 were aligned with Group 1, and the vectors for EL, A3, D3 and D5 were aligned with Group 2 
Table 3. Anatomical landmarks defined along the body contour of Scomber colias and associated geometric distances used to perform the body-morphometric analyses (from Erguden et al. 2009)

\begin{tabular}{|c|c|c|}
\hline Landmark & Location & $\begin{array}{l}\text { Body-morphometric } \\
\text { distances }\end{array}$ \\
\hline L1 & Anterior tip of snout at upper jaw & $\begin{array}{l}\text { 1: } \mathrm{L} 1 \text { to } \mathrm{L} 2 \\
\text { 2: } \mathrm{L} 1 \text { to } \mathrm{L} 12 \\
\text { 3: } \mathrm{L} 1 \text { to } \mathrm{L} 13\end{array}$ \\
\hline L2 & $\begin{array}{l}\text { Most posterior aspect of neurocranium } \\
\text { (beginning of scaled nape) }\end{array}$ & $\begin{array}{l}\text { 4: L2 to L3 } \\
\text { 5: L2 to L11 } \\
\text { 6: L2 to L12 } \\
\text { 7: L2 to L13 }\end{array}$ \\
\hline L3 & Origin of dorsal fin & $\begin{array}{l}\text { 8: } \mathrm{L} 3 \text { to } \mathrm{L} 4 \\
\text { 9: } \mathrm{L} 3 \text { to } \mathrm{L} 11 \\
\text { 10: } \mathrm{L} 3 \text { to } \mathrm{L} 12 \\
\text { 11: L3 to } \mathrm{L} 10\end{array}$ \\
\hline L4 & Insertion of dorsal fin & $\begin{array}{l}\text { 12: L4 to L5 } \\
\text { 13: L4 to L10 } \\
\text { 14: L4 to L11 }\end{array}$ \\
\hline L5 & Origin of second dorsal fin & $\begin{array}{l}\text { 15: L5 to L6 } \\
\text { 16: L5 to L10 }\end{array}$ \\
\hline L6 & Insertion of second dorsal fin & $\begin{array}{l}\text { 17: L6 to L7 } \\
\text { 18: L6 to L9 } \\
\text { 19: L6 to L10 }\end{array}$ \\
\hline L7 & $\begin{array}{l}\text { Anterior attachment of dorsal } \\
\text { membrane from caudal fin }\end{array}$ & $\begin{array}{l}\text { 20: L7 to L8 } \\
\text { 21: L7 to L9 } \\
\text { 22: L7 to L10 }\end{array}$ \\
\hline L8 & Posterior end of vertebrae column & 23: L8 to L9 \\
\hline L9 & $\begin{array}{l}\text { Anterior attachment of ventral } \\
\text { membrane from caudal fin }\end{array}$ & 24: L9 to L10 \\
\hline $\mathrm{L} 10$ & Insertion of anal fin & 25: L10 to L11 \\
\hline L11 & Origin of anal fin & 26: L11 to L12 \\
\hline L12 & Insertion of pelvic fin & 27: L12 to L13 \\
\hline L13 & Posterior most point of maxillary & \\
\hline
\end{tabular}

(Fig. 5a). A similar scenario was obtained using EFDs alone. But the combined use of SIs and EFDs gave a more robust reclassification accuracy.

Concerning body morphometrics, the univariate test showed significant differences for all 27 DT (one-way ANOVAs, d.f. $=5264, P<0.05)$. Tukey post hoc $(P<0.05)$ results showed the existence of differences among the sampling locations, but without any recognised pattern (Table 4). The multivariate tests showed significant differences for DT among all regions (PERMANOVA: pseudo- $F=19.115$, d.f. $=5264$, $P<0.05$; and pseudo-t-tests: $P<0.05)$. Jackknife reclassification accuracies showed a good overall reclassification success of $74 \%$ (Table 5). Samples from Canaries (91\%) showed the best re-classification success. The misclassification was more common within the samples from Matosinhos (47\%). LDFA plot was able to clearly isolate Canaries from the other locations (Fig. 4b). In addition, the samples that overlapped the most were from the Portuguese coast (Matosinhos, Portimão and Sesimbra) and also between Azores and Madeira. So, it was possible to observe three groups, namely, Canaries (Group 1), Azores and Madeira (Group 2), and Matosinhos, Portimão and Sesimbra (Group 3) in CAP plot (Fig. 5b). The vectors for DT8 and DT11 were aligned with
Group 1, the vectors for DT9, DT14, DT19, DT22 and DT26 were aligned with Group 2, and the vectors for DT1, DT2 and DT3 were aligned with Group 3. DT8 and DT11 had the biggest influence on the discrimination of Group 1, DT9, DT14, DT19, DT22 and DT26 on the discrimination of Group 2, and DT1, DT2 and DT3 on the discrimination of Group 3. DT8 and DT11 are more related to the length of the dorsal fin and the distance from the origin of dorsal fin to the origin of anal fin, and, in Canaries, fish presented bigger traits for both. DT9, DT14, DT19, DT22 and DT26 are related to the height and length of the fish, and Azores and Madeira showed larger traits for them. The DT1, DT2 and DT3 are related to head length and mouth size, and mainland Portugal showed larger traits for them than did the Atlantic islands.

Using the otolith shape and body morphometrics combined, the allocation of samples improved the overall re-classification success to $82 \%$ (Table 5). Samples from Azores, Canaries and Madeira were more frequently assigned to the original locations. The best classification percentage was obtained for Azores (91\%) and Canaries (91\%), followed by Madeira (87\%), with some individuals being allocated mainly in the first two islands. The mis-classification was common within the samples from Matosinhos (69\%), with samples from Portimão and Sesimbra being more frequently wrongly allocated here. In addition, the samples that overlapped the most were from the Portuguese coast (Matosinhos, Portimão and Sesimbra) and also the ones from Azores and Madeira. Therefore, LDFA plots were able to clearly isolate fish from Canaries, Azores-Madeira and mainland Portugal (Fig. 4c). Consequently, using CAP, it was possible to observe the following three groups: Canaries (Group 1), Azores and Madeira (Group 2), and Matosinhos, Portimão and Sesimbra (Group 3; Fig. 5c). Vectors for DT8 and DT11 were aligned with Group 1, the vectors for distances DT5, DT22 and DT26 were aligned with Group 2, and the vectors for distances DT1, DT2 and DT3 were aligned with Group 3. Moreover, multivariate statistics (PERMANOVA: pseudo- $F=12.13$, d.f. $=5264$, $P<0.05$ ) and all pair-wise comparisons (pseudo- $t$-tests: $P<0.05)$ gave significant results among all locations.

\section{Discussion}

The otolith form provides a phenotypic basis for the separation of fish populations, considering that the otolith morphology varies geographically according to the genetic input and local environmental factors (Cardinale et al. 2004). Otolith-shape analyses have proven to be an efficient tool to unravel the population structure of related small pelagic species in the North-east Atlantic, such as the herring (Clupea harengus; Burke et al. 2008), the European sardine (Sardina pilchardus; Jemaa et al. 2015) and the blue jack mackerel (Trachurus picturatus; Moreira et al. 2019a). Moreover, methods encoding otolith shape usually hold better classification accuracies when performed using datasets containing otoliths from juvenile fish within a single year class (Mapp et al. 2017).

The results of otolith-shape analyses alone showed that although a few spatial variations among sampling locations exist, the individuals, especially in the Atlantic islands and the mainland Portugal, highly overlapped. Data showed that misclassification occurred mainly among the individuals within the 
Table 4. Results from the univariate statistics (one-way ANOVA and Tukey post hoc tests, only if $P<0.05$ ), applied on otolith shape indices (SIs), elliptical Fourier descriptors (EFDs) and body-morphometric distances (DT)

Values are means \pm s.e. See Table 2 for definition of shape-index abbreviations. Within each row, values followed by the same letter are not statistically significantly different (at $P=0.05$ )

\begin{tabular}{|c|c|c|c|c|c|c|}
\hline Parameter & Azores & Canaries & Madeira & Matosinhos & Portimão & Sesimbra \\
\hline \multicolumn{7}{|l|}{ SIs } \\
\hline $\mathrm{FF}$ & $0.520 \pm 0.003 a$ & $0.524 \pm 0.003 a$ & $0.536 \pm 0.003 \mathrm{a}$ & $0.521 \pm 0.004 \mathrm{a}$ & $0.532 \pm 0.003 \mathrm{a}$ & $0.526 \pm 0.003 \mathrm{a}$ \\
\hline EL & $0.331 \pm 0.003 \mathrm{a}$ & $0.335 \pm 0.002 \mathrm{a}, \mathrm{b}$ & $0.330 \pm 0.003 \mathrm{a}$ & $0.337 \pm 0.003 \mathrm{a}, \mathrm{b}$ & $0.340 \pm 0.003 \mathrm{a}, \mathrm{b}$ & $0.343 \pm 0.004 b$ \\
\hline CI & $1.369 \pm 0.004 \mathrm{a}$ & $1.364 \pm 0.004 \mathrm{a}$ & $1.362 \pm 0.004 \mathrm{a}$ & $1.368 \pm 0.005 \mathrm{a}$ & $1.355 \pm 0.003 \mathrm{a}$ & $0.798 \pm 0.004 \mathrm{a}$ \\
\hline $\mathrm{RE}$ & $0.796 \pm 0.003 \mathrm{a}$ & $0.807 \pm 0.003 \mathrm{a}, \mathrm{b}$ & $0.819 \pm 0.004 b$ & $0.794 \pm 0.003 \mathrm{a}$ & $0.796 \pm 0.003 \mathrm{a}$ & $0.418 \pm 0.003 \mathrm{a}$ \\
\hline D1 & $0.418 \pm 0.003 \mathrm{a}, \mathrm{b}$ & $0.418 \pm 0.002 \mathrm{a}, \mathrm{b}$ & $0.423 \pm 0.003 \mathrm{a}$ & $0.419 \pm 0.003 \mathrm{a}, \mathrm{b}$ & $0.410 \pm 0.003 b$ & $0.418 \pm 0.003 \mathrm{a}, \mathrm{b}$ \\
\hline $\mathrm{A} 2$ & $0.0094 \pm 0.001 b$ & $0.024 \pm 0.002 \mathrm{a}$ & $0.015 \pm 0.002 b$ & $0.011 \pm 0.002 b$ & $0.012 \pm 0.002 b$ & $0.016 \pm 0.001 \mathrm{a}, \mathrm{b}$ \\
\hline B2 & $0.019 \pm 0.003 b$ & $0.030 \pm 0.001 \mathrm{a}$ & $0.027 \pm 0.001 \mathrm{a}, \mathrm{b}$ & $0.024 \pm 0.002 \mathrm{a}, \mathrm{b}$ & $0.030 \pm 0.001 \mathrm{a}$ & $0.028 \pm 0.002 \mathrm{a}$ \\
\hline $\mathrm{C} 2$ & $-0.009 \pm 0.001 \mathrm{a}$ & $-0.006 \pm 0.002 \mathrm{a}$ & $-0.013 \pm 0.002 \mathrm{a}$ & $-0.010 \pm 0.003 \mathrm{a}$ & $-0.013 \pm 0.002 \mathrm{a}$ & $-0.008 \pm 0.002 \mathrm{a}$ \\
\hline D2 & $0.064 \pm 0.001 \mathrm{a}$ & $0.065 \pm 0.001 \mathrm{a}$ & $0.059 \pm 0.001 b$ & $0.056 \pm 0.001 b$ & $0.058 \pm 0.001 b$ & $0.055 \pm 0.001 b$ \\
\hline A3 & $0.036 \pm 0.001 b$ & $0.030 \pm 0.001 \mathrm{a}$ & $0.036 \pm 0.001 b$ & $0.049 \pm 0.001 \mathrm{c}$ & $0.044 \pm 0.001 \mathrm{c}$ & $0.045 \pm 0.002 \mathrm{c}$ \\
\hline B3 & $0.005 \pm 0.001 \mathrm{a}$ & $0.001 \pm 0.001 \mathrm{a}$ & $0.004 \pm 0.001 \mathrm{a}$ & $0.002 \pm 0.001 \mathrm{a}$ & $0.0001 \pm 0.001 \mathrm{a}$ & $0.002 \pm 0.001 \mathrm{a}$ \\
\hline $\mathrm{C} 3$ & $-0.005 \pm 0.001 \mathrm{a}$ & $-0.007 \pm 0.001 \mathrm{a}, \mathrm{b}$ & $-0.013 \pm 0.001 b, c$ & $-0.011 \pm 0.002 \mathrm{a}, \mathrm{b}, \mathrm{c}$ & $-0.016 \pm 0.002 \mathrm{c}$ & $-0.011 \pm 0.002 \mathrm{a}, \mathrm{b}, \mathrm{c}$ \\
\hline A4 & $-0.010 \pm 0.001 \mathrm{a}, \mathrm{c}$ & $-0.008 \pm 0.001 \mathrm{a}, \mathrm{b}, \mathrm{c}$ & $-0.011 \pm 0.001 \mathrm{a}$ & $-0.0064 \pm 0.0009 b, c$ & $-0.008 \pm 0.001 \mathrm{a}, \mathrm{c}$ & $-0.004 \pm 0.001 b$ \\
\hline B4 & $0.018 \pm 0.003 b$ & $0.028 \pm 0.001 \mathrm{a}$ & $0.021 \pm 0.001 \mathrm{a}, \mathrm{b}$ & $0.022 \pm 0.001 \mathrm{a}, \mathrm{b}$ & $0.026 \pm 0.001 \mathrm{a}, \mathrm{b}$ & $0.024 \pm 0.001 \mathrm{a}, \mathrm{b}$ \\
\hline $\mathrm{C} 4$ & $0.020 \pm 0.003 \mathrm{a}$ & $0.0229 \pm 0.0009 \mathrm{a}$ & $0.024 \pm 0.001 \mathrm{a}$ & $0.025 \pm 0.001 \mathrm{a}$ & $0.0235 \pm 0.0009 \mathrm{a}$ & $0.023 \pm 0.001 \mathrm{a}$ \\
\hline D4 & $0.041 \pm 0.001 \mathrm{a}$ & $0.042 \pm 0.001 \mathrm{a}$ & $0.041 \pm 0.001 \mathrm{a}$ & $0.038 \pm 0.001 \mathrm{a}$ & $0.042 \pm 0.001 \mathrm{a}$ & $0.038 \pm 0.001 \mathrm{a}$ \\
\hline A5 & $0.0024 \pm 0.0008 \mathrm{a}$ & $0.004 \pm 0.001 \mathrm{a}$ & $0.003 \pm 0.001 \mathrm{a}$ & $0.0049 \pm 0.0008 \mathrm{a}$ & $0.0041 \pm 0.0009 \mathrm{a}$ & $0.004 \pm 0.001 \mathrm{a}$ \\
\hline B5 & $0.001 \pm 0.001 b$ & $-0.006 \pm 0.001 \mathrm{a}, \mathrm{c}$ & $-0.004 \pm 0.001 \mathrm{a}, \mathrm{b}, \mathrm{d}$ & $-0.006 \pm 0.001 \mathrm{c}, \mathrm{d}$ & $-0.009 \pm 0.001 \mathrm{c}$ & $-0.008 \pm 0.001 \mathrm{a}, \mathrm{c}, \mathrm{d}$ \\
\hline $\mathrm{C} 5$ & $0.0002 \pm 0.001 \mathrm{a}$ & $-0.0006 \pm 0.0007 \mathrm{a}, \mathrm{b}$ & $-0.003 \pm 0.001 \mathrm{a}, \mathrm{b}$ & $-0.0034 \pm 0.0007 b$ & $-0.003 \pm 0.001 \mathrm{a}, \mathrm{b}$ & $-0.0038 \pm 0.0009 b$ \\
\hline D5 & $-0.0213 \pm 0.0006 b$ & $-0.0182 \pm 0.0008 \mathrm{a}$ & $-0.016 \pm 0.001 \mathrm{a}$ & $-0.0160 \pm 0.0007 \mathrm{a}$ & $-0.0168 \pm 0.0006 \mathrm{a}$ & $-0.0155 \pm 0.0008 \mathrm{a}$ \\
\hline A6 & $-0.0253 \pm 0.001 \mathrm{a}, \mathrm{c}$ & $-0.028 \pm 0.001 \mathrm{a}, \mathrm{c}$ & $-0.028 \pm 0.001 \mathrm{a}$ & $-0.0210 \pm 0.0009 b$ & $-0.027 \pm 0.001 b, c$ & $-0.019 \pm 0.001 b$ \\
\hline B6 & $0.017 \pm 0.003 b$ & $0.0260 \pm 0.0009 \mathrm{a}$ & $0.021 \pm 0.001 \mathrm{a}, \mathrm{b}$ & $0.022 \pm 0.001 \mathrm{a}, \mathrm{b}$ & $0.025 \pm 0.001 \mathrm{a}$ & $0.025 \pm 0.001 \mathrm{a}$ \\
\hline C6 & $-0.0038 \pm 0.0008 \mathrm{a}, \mathrm{b}$ & $-0.0066 \pm 0.0006 \mathrm{a}$ & $-0.003 \pm 0.001 b$ & $-0.0009 \pm 0.0007 b$ & $-0.0027 \pm 0.0008 b$ & $-0.0010 \pm 0.0006 b$ \\
\hline \multicolumn{7}{|l|}{ DT } \\
\hline 1 & $1.587 \pm 0.003 \mathrm{a}$ & $1.619 \pm 0.003 b, c$ & $1.594 \pm 0.003 \mathrm{a}$ & $1.613 \pm 0.003 b$ & $1.614 \pm 0.003 b$ & $1.626 \pm 0.003 c$ \\
\hline 2 & $1.795 \pm 0.001 \mathrm{a}$ & $1.792 \pm 0.001 \mathrm{a}$ & $1.790 \pm 0.001 \mathrm{a}$ & $1.802 \pm 0.001 b$ & $1.804 \pm 0.001 b$ & $1.811 \pm 0.001 \mathrm{c}$ \\
\hline 3 & $1.394 \pm 0.002 \mathrm{a}$ & $1.431 \pm 0.003 \mathrm{~b}, \mathrm{c}$ & $1.408 \pm 0.002 \mathrm{~d}$ & $1.415 \pm 0.002 \mathrm{~d}, \mathrm{e}$ & $1.422 \pm 0.002 \mathrm{~b}, \mathrm{e}$ & $1.435 \pm 0.003 \mathrm{c}$ \\
\hline 7 & $1.489 \pm 0.002 \mathrm{a}, \mathrm{b}$ & $1.506 \pm 0.002 \mathrm{c}$ & $1.483 \pm 0.003 \mathrm{a}$ & $1.500 \pm 0.003 \mathrm{c}$ & $1.503 \pm 0.003 c$ & $1.498 \pm 0.003 \mathrm{~b}, \mathrm{c}$ \\
\hline 8 & $1.440 \pm 0.003 \mathrm{a}, \mathrm{b}$ & $1.475 \pm 0.004 \mathrm{c}$ & $1.442 \pm 0.004 \mathrm{a}, \mathrm{b}$ & $1.429 \pm 0.006 \mathrm{a}$ & $1.438 \pm 0.004 \mathrm{a}, \mathrm{b}$ & $1.452 \pm 0.004 b$ \\
\hline 9 & $1.849 \pm 0.001 \mathrm{a}$ & $1.846 \pm 0.001 \mathrm{a}$ & $1.847 \pm 0.001 \mathrm{a}$ & $1.846 \pm 0.002 \mathrm{a}$ & $1.839 \pm 0.002 b$ & $1.831 \pm 0.001 \mathrm{c}$ \\
\hline 10 & $1.562 \pm 0.003 \mathrm{a}$ & $1.558 \pm 0.002 \mathrm{a}, \mathrm{b}$ & $1.535 \pm 0.003 \mathrm{c}$ & $1.548 \pm 0.004 b$ & $1.526 \pm 0.003 \mathrm{c}$ & $1.528 \pm 0.002 \mathrm{c}$ \\
\hline 11 & $1.918 \pm 0.001 \mathrm{a}$ & $1.928 \pm 0.001 b$ & $1.916 \pm 0.001 \mathrm{a}, \mathrm{c}$ & $1.919 \pm 0.001 \mathrm{a}$ & $1.918 \pm 0.001 \mathrm{a}$ & $1.911 \pm 0.001 \mathrm{c}$ \\
\hline 12 & $1.482 \pm 0.003 \mathrm{a}, \mathrm{b}$ & $1.459 \pm 0.005 \mathrm{c}$ & $1.468 \pm 0.004 \mathrm{a}, \mathrm{c}$ & $1.489 \pm 0.006 b$ & $1.467 \pm 0.005 \mathrm{a}, \mathrm{c}$ & $1.457 \pm 0.005 \mathrm{c}$ \\
\hline 13 & $1.759 \pm 0.002 \mathrm{a}$ & $1.755 \pm 0.002 \mathrm{a}$ & $1.752 \pm 0.002 \mathrm{a}$ & $1.761 \pm 0.004 \mathrm{a}$ & $1.755 \pm 0.002 \mathrm{a}$ & $1.739 \pm 0.002 b$ \\
\hline 14 & $1.673 \pm 0.002 \mathrm{a}$ & $1.655 \pm 0.002 b$ & $1.666 \pm 0.002 \mathrm{a}, \mathrm{b}$ & $1.670 \pm 0.004 \mathrm{a}$ & $1.657 \pm 0.002 b$ & $1.634 \pm 0.003 c$ \\
\hline 15 & $1.288 \pm 0.004 \mathrm{a}, \mathrm{b}$ & $1.305 \pm 0.004 \mathrm{a}$ & $1.286 \pm 0.006 \mathrm{~b}, \mathrm{c}$ & $1.277 \pm 0.006 \mathrm{~b}$ & $1.298 \pm 0.004 \mathrm{a}, \mathrm{c}$ & $1.285 \pm 0.004 b, c$ \\
\hline 16 & $1.510 \pm 0.003 \mathrm{a}, \mathrm{b}$ & $1.517 \pm 0.002 \mathrm{a}$ & $1.508 \pm 0.002 \mathrm{a}, \mathrm{b}$ & $1.504 \pm 0.003 b$ & $1.508 \pm 0.002 \mathrm{a}, \mathrm{b}$ & $1.484 \pm 0.002 \mathrm{c}$ \\
\hline 17 & $1.586 \pm 0.002 \mathrm{a}$ & $1.587 \pm 0.002 \mathrm{a}$ & $1.587 \pm 0.003 \mathrm{a}$ & $1.585 \pm 0.004 \mathrm{a}, \mathrm{b}$ & $1.578 \pm 0.003 \mathrm{a}, \mathrm{b}$ & $1.574 \pm 0.003 b$ \\
\hline 18 & $1.598 \pm 0.002 \mathrm{a}, \mathrm{b}$ & $1.597 \pm 0.002 \mathrm{a}, \mathrm{b}$ & $1.600 \pm 0.003 \mathrm{a}$ & $1.598 \pm 0.004 \mathrm{a}, \mathrm{b}$ & $1.594 \pm 0.002 \mathrm{a}, \mathrm{b}$ & $1.589 \pm 0.003 b$ \\
\hline 19 & $1.348 \pm 0.003 \mathrm{a}$ & $1.344 \pm 0.003 \mathrm{a}$ & $1.340 \pm 0.002 \mathrm{a}$ & $1.335 \pm 0.005 \mathrm{a}, \mathrm{b}$ & $1.323 \pm 0.003 b$ & $1.299 \pm 0.003 c$ \\
\hline 20 & $0.982 \pm 0.005 \mathrm{a}, \mathrm{c}$ & $0.930 \pm 0.008 b$ & $1.001 \pm 0.006 \mathrm{a}$ & $0.979 \pm 0.006 \mathrm{a}, \mathrm{c}$ & $0.961 \pm 0.005 \mathrm{c}$ & $0.971 \pm 0.005 \mathrm{c}$ \\
\hline 21 & $0.827 \pm 0.004 \mathrm{a}$ & $0.829 \pm 0.005 \mathrm{a}$ & $0.811 \pm 0.004 \mathrm{a}, \mathrm{b}$ & $0.784 \pm 0.005 \mathrm{c}, \mathrm{d}$ & $0.797 \pm 0.004 b, c$ & $0.779 \pm 0.004 \mathrm{~d}$ \\
\hline 22 & $1.607 \pm 0.002 \mathrm{a}$ & $1.601 \pm 0.002 \mathrm{a}$ & $1.597 \pm 0.002 \mathrm{a}$ & $1.588 \pm 0.002 b$ & $1.581 \pm 0.003 b$ & $1.583 \pm 0.002 b$ \\
\hline 23 & $0.995 \pm 0.004 \mathrm{a}, \mathrm{b}$ & $0.993 \pm 0.007 \mathrm{a}, \mathrm{b}$ & $1.008 \pm 0.005 \mathrm{a}$ & $0.981 \pm 0.007 \mathrm{~b}, \mathrm{c}$ & $0.969 \pm 0.005 \mathrm{c}$ & $0.977 \pm 0.005 \mathrm{~b}, \mathrm{c}$ \\
\hline 24 & $1.577 \pm 0.002 \mathrm{a}$ & $1.567 \pm 0.00 \mathrm{~b}$ & $1.570 \pm 0.002 \mathrm{a}, \mathrm{b}$ & $1.563 \pm 0.002 b, c$ & $1.556 \pm 0.003 \mathrm{c}$ & $1.561 \pm 0.002 b, c$ \\
\hline 25 & $1.197 \pm 0.005 \mathrm{a}$ & $1.237 \pm 0.005 b$ & $1.167 \pm 0.005 \mathrm{c}$ & $1.198 \pm 0.005 \mathrm{a}, \mathrm{d}$ & $1.216 \pm 0.005 \mathrm{a}, \mathrm{d}$ & $1.219 \pm 0.005 \mathrm{~b}, \mathrm{~d}$ \\
\hline 26 & $1.855 \pm 0.001 \mathrm{a}$ & $1.839 \pm 0.002 b, c$ & $1.864 \pm 0.002 \mathrm{~d}$ & $1.846 \pm 0.002 \mathrm{e}$ & $1.844 \pm 0.002 \mathrm{~b}, \mathrm{e}$ & $1.832 \pm 0.002 \mathrm{c}$ \\
\hline 27 & $1.588 \pm 0.002 \mathrm{a}$ & $1.563 \pm 0.002 b$ & $1.575 \pm 0.002 \mathrm{c}$ & $1.587 \pm 0.002 \mathrm{a}$ & $1.590 \pm 0.002 \mathrm{a}$ & $1.588 \pm 0.0 .002 \mathrm{a}$ \\
\hline
\end{tabular}


Table 5. Jackknifed re-classification matrix resulting from the complete discriminant linear function analyses for otolith shape (shape index (SI) + elliptical Fourier descriptor (EFD)), body morphometrics (DT), and a combination of all three (SIs + EFDs + DT) of Scomber colias

\begin{tabular}{|c|c|c|c|c|c|c|c|}
\hline \multirow[t]{2}{*}{ Original location } & \multicolumn{6}{|c|}{ Predicted location } & \multirow[t]{2}{*}{ Percentage correc } \\
\hline & Azores & Canaries & Madeira & Matosinhos & Portimão & Sesimbra & \\
\hline \multicolumn{8}{|l|}{ SIs + EFDs } \\
\hline Azores & 24 & 8 & 8 & 2 & 2 & 1 & 53 \\
\hline Canaries & 4 & 33 & 5 & 0 & 2 & 1 & 73 \\
\hline Madeira & 7 & 10 & 23 & 2 & 2 & 1 & 51 \\
\hline Matosinhos & 0 & 0 & 1 & 26 & 7 & 11 & 58 \\
\hline Portimão & 0 & 3 & 5 & 5 & 20 & 12 & 44 \\
\hline Sesimbra & 2 & 0 & 2 & 15 & 13 & 13 & 29 \\
\hline Total & 37 & 54 & 44 & 50 & 46 & 39 & 51 \\
\hline \multicolumn{8}{|l|}{ DT } \\
\hline Azores & 35 & 0 & 6 & 3 & 1 & 0 & 78 \\
\hline Canaries & 1 & 41 & 1 & 1 & 1 & 0 & 91 \\
\hline Madeira & 6 & 0 & 35 & 2 & 2 & 0 & 78 \\
\hline Matosinhos & 6 & 0 & 4 & 21 & 6 & 8 & 47 \\
\hline Portimão & 1 & 1 & 1 & 5 & 32 & 5 & 71 \\
\hline Sesimbra & 1 & 0 & 0 & 6 & 2 & 36 & 80 \\
\hline Total & 50 & 42 & 47 & 38 & 44 & 49 & 74 \\
\hline \multicolumn{8}{|l|}{ SIs + EFDs + DT } \\
\hline Azores & 41 & 0 & 2 & 2 & 0 & 0 & 91 \\
\hline Canaries & 2 & 41 & 1 & 1 & 0 & 0 & 91 \\
\hline Madeira & 4 & 1 & 39 & 0 & 1 & 0 & 87 \\
\hline Matosinhos & 0 & 0 & 1 & 31 & 4 & 9 & 69 \\
\hline Portimão & 0 & 1 & 2 & 3 & 34 & 5 & 76 \\
\hline Sesimbra & 0 & 0 & 0 & 4 & 6 & 35 & 78 \\
\hline Total & 47 & 43 & 45 & 41 & 45 & 49 & 82 \\
\hline
\end{tabular}

islands (Azores, Madeira and Canaries) and the mainland Portugal (Matosinhos, Portimão and Sesimbra). Moreover, the visual inspection of DFA and CAP plots suggested a discrete separation of two main groups (Islands: Canaries + Azores + Madeira vs mainland Portugal: Matosinhos + Portimão + Sesimbra), being mainly driven by A2, A3, D3, D5, B5, D2, EL RE and RO.

The hereby observed differences in otolith shape between the islands and the Portuguese coast could be attributed to quite different environmental conditions, such as water temperature and feeding regimes, which, in turn, affect species growth rate and, consequently, the shape of otoliths (Campana and Casselman 1993; Vignon and Morat 2010; Mille et al. 2016). There are known differences between the oligotrophic waters of the Atlantic oceanic islands and the highly productive Portuguese coastal waters (Moreira et al. 2018), partially as a result of the coastal upwelling in the Portuguese coast that promotes the enrichment of the inshore area with nutrients (Santos et al. 2007). Moreover, Madeira and Canaries are located in an ecoregion characterised by a singular bathymetry, hydrography and productivity (Hernández-León et al. 2007). The region of Madeira is dominated by the Canary Current system, which induces a southward net transport (Caldeira and Sangrà 2012), but the presence of a seamount at the south-eastern end of Madeira produces a localised island upwelling of cold nutrient-rich waters around the coast (Caldeira et al. 2002). Furthermore, Canaries also suffer the influence on the first $500 \mathrm{~m}$ of depth of the eastern North Atlantic Central Water
(Hernández-Guerra et al. 2002). These distinct oceanographic characteristics may affect the diet, metabolism and, consequently, the growth rate of fish, contributing to the observed variations in the otolith shape (Moreira et al. 2019a).

The body morphometrics are also useful to discriminate fishstock structure of various exploited marine fish species (Erguden et al. 2009; Allaya et al. 2013; Kaouèche et al. 2017). In the present study, body morphological data (all DT) showed the strongest significant differences among sampling groups. Moreover, the multivariate analyses showed a clear distinction between Canaries and the other regions. A separation was also observed between the samples from the Portuguese coast (Matosinhos, Portimão and Sesimbra) and the AzoresMadeira. The length of the dorsal fin and the distance from the origin of dorsal fin to the origin of anal fin were greater in the samples from Canaries, the height and length of the fish were greater in the samples from Azores-Madeira, and the head length and mouth size were larger in the samples from mainland Portugal. Thus, body morphometry shows, instead, three main populations, i.e. Canaries, Azores-Madeira and mainland Portugal, suggesting that it is a better tool than otolith-shape analyses for stock-discrimination purposes in this species.

The hereby observed differences in morphometric characteristics of $S$. colias among these regions may be related to a migratory feeding strategy (Roldán et al. 2000). A study conducted in Canaries with $S$. colias affirmed that the carrying capacity is limited in the shallow coastal waters and probably, in combination with other factors, forces juveniles to migrate 
(a)

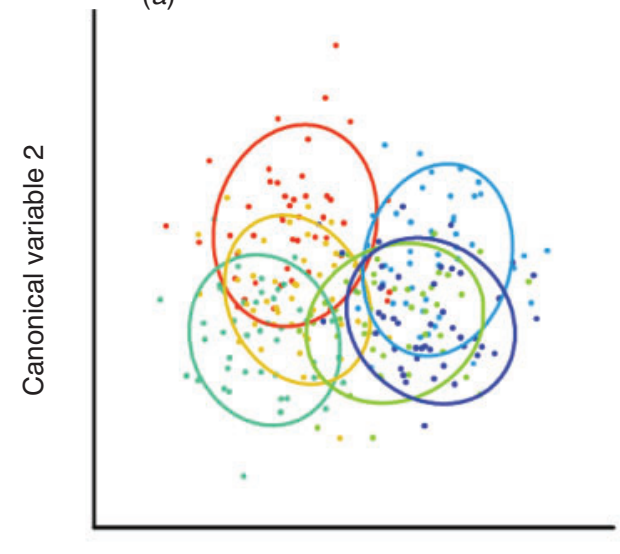

Canonical variable 1

(b)

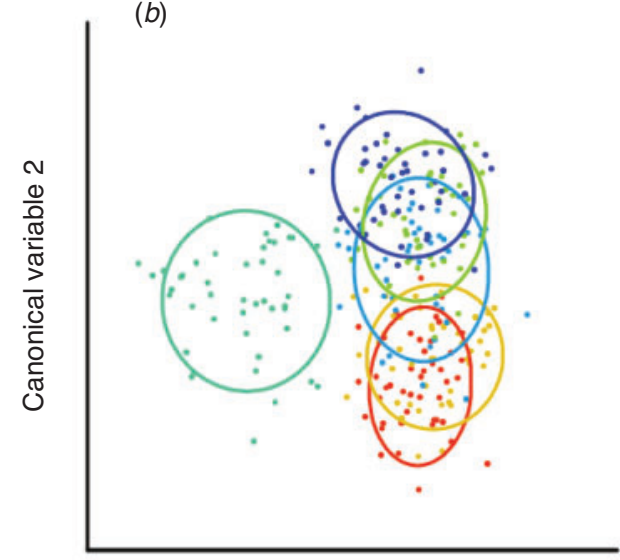

Canonical variable 1

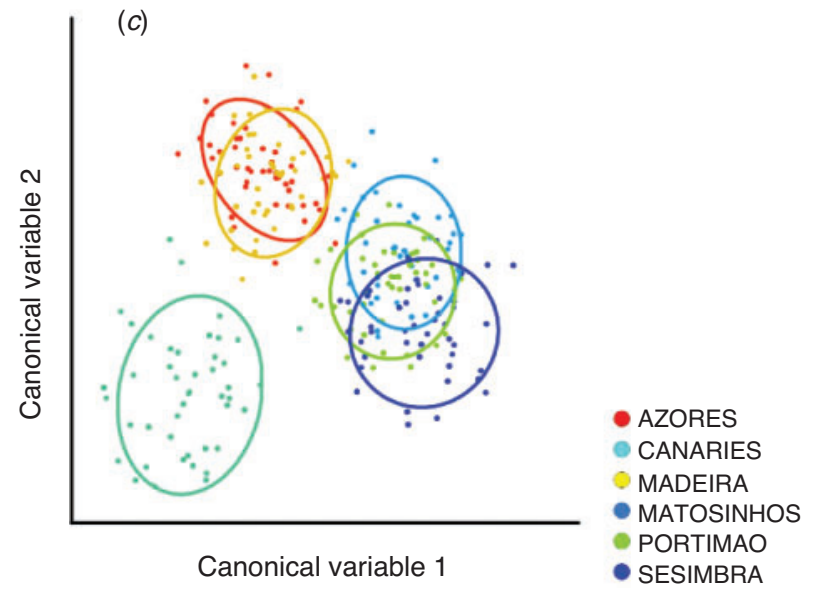

Fig. 4. Canonical variable plots show differences for $(a)$ otolith shape, (b) body morphometric, and (c) a combination of both of Scomber colias for the different sampling locations in the North-east Atlantic (Azores, Canaries, Madeira, Matosinhos, Portimão and Sesimbra). Ellipses represent 95\% confidence intervals around the data, and points represent individual fish.

offshore, where they can find enough food (Castro 1993). Moreover, fish are known to exhibit a large component of environmentally induced morphological variation, which might
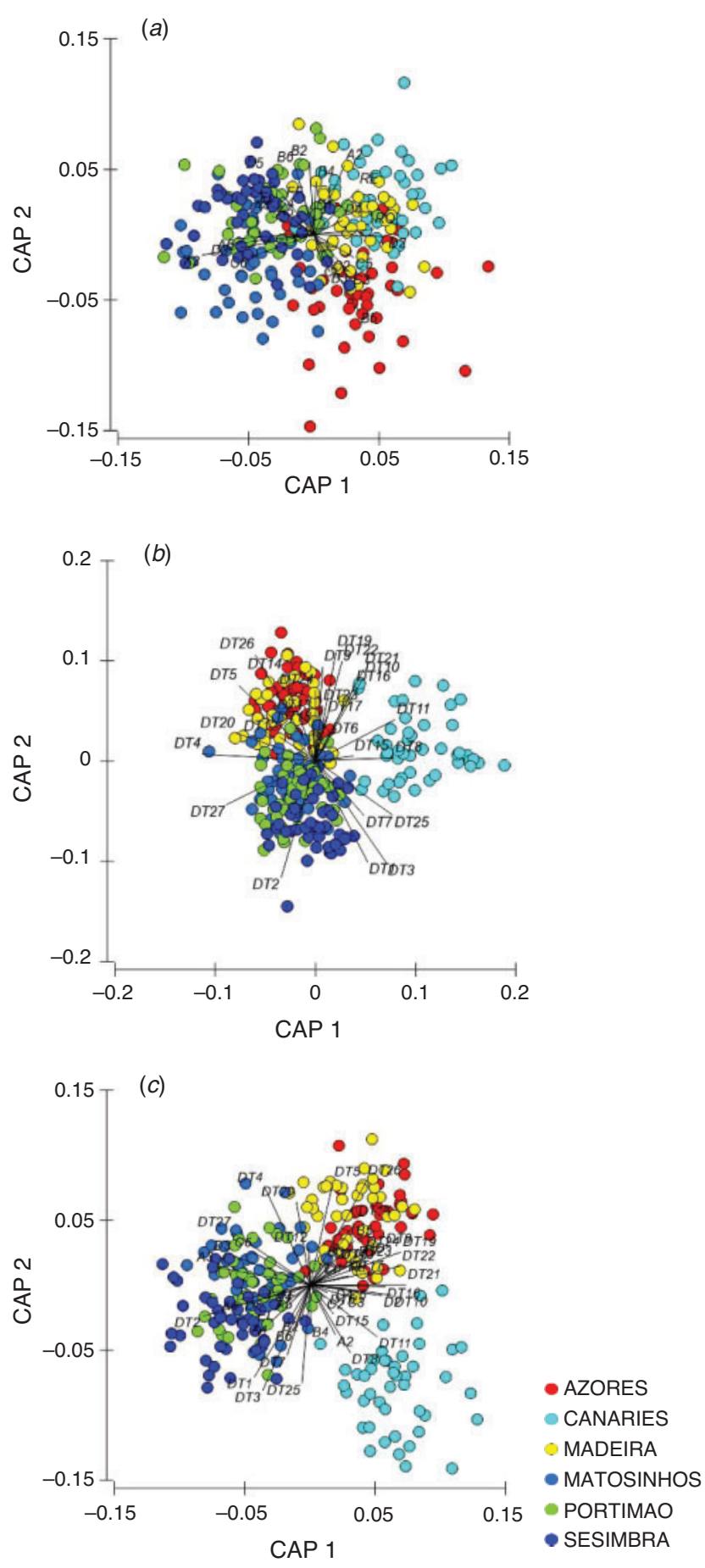

Fig. 5. Canonical analysis of principal-coordinate plots (CAP) show differences for $(a)$ otolith shape, $(b)$ body morphometric, and (c) a combination of both of Scomber colias for the different sampling locations in the North-east Altlantic (Azores, Canaries, Madeira, Matosinhos, Portimão and Sesimbra). Solid black lines represent the vectors, and points represent individual fish.

reflect different feeding strategies and developmental environments (Allaya et al. 2013). Furthermore, the same authors suggested that the high body-morphological differentiation 
among three sampling sites along the coast of Tunisia for $S$. colias could be caused by differences in genetic structure or environmental parameters (Allaya et al. 2016). A study reported that an increase in the length of the body of the Atlantic chub mackerel, previously named $S$. japonicas, was correlated with a decreasing head size, which is related to a migratory feeding strategy (Perrotta et al. 1999). Another study on S. colias in the south-western Atlantic Ocean also suggested that the recorded greater head length, but lower mouth width and interorbital length, were primary characteristics differentiating among stocks (Roldán et al. 2000). More recently, a work undertaken with $S$. colias in the Black, Marmara, Aegean and Mediterranean seas also identified regional differences between the sizes of the head and the mouth, and attributed them to growth responses to the differing habitats arising from oceanographic and ecological conditions (Erguden et al. 2009). Thus, the hereby observed regional variation in $S$. colias, mainly in head width and mouth size, may be the result of individual feeding adaptations to different environments.

Similarly to other works (Vergara-Solana et al. 2013; Rodgveller et al. 2017; Vasconcelos et al. 2018), the use of a combination of tools (otolith-shape analyses and body geometric morphometrics) improved the re-classification success and confirmed the existence of three population units of $S$. colias in the North-east Atlantic. In addition, the three sites within the region of mainland Portugal exhibited a high overlap of individuals, suggesting a high connectivity at short geographic scales. The separation among the main three regions probably resulted from genetic and environmental differences that could have affected the body and otolith shapes, and may be indicative of spatial stock structure. Similar findings have recently been reported in the North-east Atlantic for T. picturatus (Moreira et al. 2018, 2019a), suggesting that these small pelagic fish, both being collected by the multi-species purseseine fleets (Feijó et al. 2018), could share a similar population-structure scenario.

Although molecular markers, namely mtDNA, show weak genetic structure among marine pelagic fish (Chlaida et al. 2009; Kasapidis et al. 2012; Moreira et al. 2019b), a single stock of $S$. colias has been considered until now for the Northeast Atlantic (Scoles et al. 1998; Zardoya et al. 2004). However, the present results showed significant regional differences in body geometric morphometrics and otolith-shape analyses of individuals collected in the North-east (ICES IXa and X) and eastern Centre (CECAF 34.1.2) Atlantic fishing areas for the species. The current data point out to the existence of three distinct population units for $S$. colias, suggesting that the fishery should be managed at a finer resolution than the current singlepopulation model. This study suggests a stock structure for $S$. colias, demanding regional specific requirements to ensure a sustainable resource exploitation, such as the use of multi-stock assessment models, distribution of the catches-landings among management areas and the involvement of multiple nested scales of governance (Kritzer and Liu 2013).

\section{Conflicts of interest}

The authors declare that they have no conflicts of interest to declare in the present work.

\section{Declaration of funding}

This research was partially supported by the NORTE-01-0145FEDER-000035 (MARINFO) and the Strategic Funding UID/ Multi/04423/2019 through national funds provided by Foundation for Science and Technology (FCT) and European Regional Development Fund (ERDF), in the framework of the program PT2020.

\section{Acknowledgements}

Authors acknowledge Paulo Castro (IPMA, Matosinhos), Artur Gomes (Docapesca, Sesimbra), Carolino Rodrigues (Docapesca, Portimão), Graça Faria and João Delgado (DRP, Madeira) for fish-acquisition help.

\section{References}

Allaya, H., Hattour, A., Hajjej, G., and Trabelsi, M. (2013). Biologic characteristics of Scomber japonicus (Houttuyn, 1782) in Tunisian waters (central Mediterranean Sea). African Journal of Biotechnology 12(20), 3040-3048.

Allaya, H., Ben Faleh, A., Rebaya, M., Zrelli, S., Hajjej, G., Hattour, A., Quignard, J., and Trabelsi, M. (2016). Identification of Atlantic chub mackerel Scomber colias population through the analysis of body shape in Tunisian waters. Cahiers de Biologie Marine 57, 195-207.

Azevedo, M., Silva, A., Gaspar, M., Silva, C., Murta, A., Moura, T., Santos, M., Stratoudakis, Y., Prista, N., Martins, M., Soares, E., Figueiredo, I., Moreno, A., Pereira, J., Pereira, B., Farias, I., Lagarto, N., and Chaves, C. (2012). 'Avaliação Inicial do Estado Ambiental das Populações de Peixes e Moluscos Explorados Comercialmente na ZEE Continental Portuguesa: Descritor da Directiva Quadro (DQEM).' (Instituto Nacional de Recursos Biologicos, I.P., Ministério da Agricultura, Mar, Ambiente e Ordenamento do Território: Lisboa, Portugal.)

Bacha, M., Jemaa, S., Hamitouche, A., Rabhi, K., and Amara, R. (2014). Population structure of the European anchovy, Engraulis encrasicolus, in the SW Mediterranean Sea, and the Atlantic Ocean: evidence from otolith shape analysis. ICES Journal of Marine Science 71, 2429-2435. doi:10.1093/ICESJMS/FSU097

Burke, N., Brophy, D., and King, P. A. (2008). Shape analysis of otolith annuli in Atlantic herring (Clupea harengus): a new method for tracking fish populations. Fisheries Research 91, 133-143. doi:10.1016/ J.FISHRES.2007.11.013

Cabral, H. N., Marques, J. F., Rego, A. L., Catarino, A. I., Figueiredo, J., and Garcia, J. (2003). Genetic and morphological variation of Synaptura lusitanica Capello, 1868, along the Portuguese coast. Journal of Sea Research 50, 167-175. doi:10.1016/S1385-1101(03)00060-1

Caldeira, R. M. A., and Sangrà, P. (2012). Complex geophysical wake flows. Ocean Dynamics 62(5), 683-700. doi:10.1007/S10236-012-0528-6

Caldeira, R. M. A., Groom, S., Miller, P., Pilgrim, D., and Nezlin, N. P. (2002). Sea-surface signatures of the island mass effect phenomena around Madeira Island, Northeast Atlantic. Remote Sensing of Environment 80(2), 336-360. doi:10.1016/S0034-4257(01)00316-9

Campana, S. E., and Casselman, J. M. (1993). Stock discrimination using otolith shape analysis. Canadian Journal of Fisheries and Aquatic Sciences 50, 1062-1083. doi:10.1139/F93-123

Campana, S. E., Chouinard, G. A., Hanson, J. M., Fréchet, A., and Brattey, J. (2000). Otolith elemental fingerprints as biological tracers of fish stocks. Fisheries Research 46, 343-357. doi:10.1016/S0165-7836(00)00158-2

Cardinale, M., Doering-Arjes, P., Kastowsky, M., and Mosegaard, H. (2004). Effects of sex, stock, and environment on the shape of knownage Atlantic cod (Gadus morhua) otoliths. Canadian Journal of Fisheries and Aquatic Sciences 61, 158-167. doi:10.1139/F03-151

Carvalho, N., Perrota, R. G., and Isidro, E. J. (2002). Age, growth and maturity in the chub mackerel (Scomber japonicus Houttuyn, 1782) from the Azores. Arquipélago. Ciências Biológicas e Marinhas 19A, 93-99. 
Castro, J. J. (1993). Feeding ecology of chub mackerel Scomber japonicus in the Canary Islands area. South African Journal of Marine Science 13(1), 323-328. doi:10.2989/025776193784287400

Castro-Hernández, J. J., and Santana-Ortega, A. T. (2000). 'Synopsis of Biological Data on the Chub Mackerel (Scomber japonicus, 1782).' FAO Fisheries Synopsis, no. 157. (FAO: Roma, Italy.)

Catanese, G., Manchado, M., and Infante, C. (2010). Evolutionary relatedness of mackerels of the genus Scomber based on complete mitochondrial genomes: strong support to the recognition of Atlantic Scomber colias and Pacific Scomber japonicus as distinct species. Gene $\mathbf{4 5 2}$, 35-43. doi:10.1016/J.GENE.2009.12.004

Chlaida, M., Laurent, V., Kifani, S., Benazzou, T., Jaziri, H., and Planes, S. (2009). Evidence of a genetic cline for Sardina pilchardus along the northwest African coast. ICES Journal of Marine Science 66, 264-271. doi:10.1093/ICESJMS/FSN206

Collette, B. B. (1986). Scombridae. In 'Fish of the North-eastern Atlantic and the Mediterranean'. (Eds P. J. P. Whitehead, M. L. Bauchot, J. C. Hureau, J. Nielsen, and E. Tortonese.) pp. 981-997. (UNESCO: Paris.)

Collette, B. B., and Nauen, C. E. (1983). 'Scombrids of the World.' FAO Fisheries Synopsis, no. 125. (FAO: Rome, Italy.)

DGRM (2018). Recursos da pesca. Série estatística, 30 A-B, version of 2017. Available at www.dgrm.mm.gov.pt [verified 29 August 2018].

Erguden, E., Öztürk, B., Erdogan, Z. A., and Turan, C. (2009). Morphologic structuring between populations of chub mackerel Scomber japonicus in the Black, Marmara, Aegean, and northeastern Mediterranean Seas. Fisheries Science 75, 129-135. doi:10.1007/S12562-008-0032-6

European Commission (2017). The EU consumer habits. Final report Directorate-General for Maritime Affairs and Fisheries of the European Commission, Brussels.

Feijó, D., Marçalo, A., Bento, T., Barra, J., Marujo, D., Correia, M., and Silva, P. (2018). Trends in the activity pattern, fishing yields, catch and landing composition between 2009 and 2013 from onboard observations in the Portuguese purse seine fleet. Regional Studies in Marine Science 23, 97-106. doi:10.1016/J.RSMA.2017.12.007

Ferguson, G. J., Ward, T. M., and Gillanders, B. M. (2011). Otolith shape and elemental composition: complementary tools for stock discrimination of mulloway (Argyrosomus japonicus) in southern Australia. Fisheries Research 110, 75-83. doi:10.1016/J.FISHRES.2011.03.014

Gamito, R., Teixeira, M. C., Costa, M. J., and Cabral, H. N. (2015). Are the regional fisheries' catches changing with climate? Fisheries Research 161, 207-216. doi:10.1016/J.FISHRES.2014.07.014

Hernández-Guerra, A., Machín, F., Antoranz, A., Cisneros-Aguirre, J., Gordo, C., Marrero-Díaz, A., Martínez, A., Ratsimandresy, A. W., Rodríguez-Santana, A., Sangrá, P., López-Laazen, F., Parrilla, G., and Pelegrí, J. L. (2002). Temporal variability of mass transport in the Canary Current. Deep-sea Research Part II: Topical Studies in Oceanography 49(17), 3415-3426. doi:10.1016/S0967-0645(02)00092-9

Hernández-León, S., Gómez, M., and Arístegui, J. (2007). Mesozooplankton in the Canary Current System: the coastal-ocean transition zone. Progress in Oceanography 74(2-3), 397-421. doi:10.1016/ J.POCEAN.2007.04.010

Hoff, N. T., Dias, J. F., Zani-Teixeira, M. L., and Correia, A. T. (2020). Spatio-temporal evaluation of the population structure of the bigtooth corvina Isopisthus parvipinnis from Southwest Atlantic Ocean using otolith shape signatures. Journal of Applied Ichthyology, in press. doi:10. 1111/JAI.14044

ICES (2015). Report of the workshop on age reading of chub mackerel (Scomber colias) (WKARCM), Lisbon, 2-6 November 2015. ICES CM 2015\SSGEIOM:11. International Council for the Exploration of the Sea, Denmark.

Infante, C., Blanco, E., Zuasti, E., Crespo, A., and Manchado, M. (2007). Phylogenetic differentiation between Atlantic Scomber colias and Pacific Scomber japonicus based on nuclear DNA sequences. Genetica 130, 1-8. doi:10.1007/S10709-006-0014-5
IUCN (2011). Scomber colias, IUCN red list of threatened species. Available at www.iucn.org [verified 29 August 2018].

Iwata, H., and Ukai, Y. (2002). SHAPE: um pacote de programa de computador para avaliação quantitativa de formas biológicas baseada em descritores de Fourier elípticos. The Journal of Heredity 93, 384385. doi:10.1093/JHERED/93.5.384

Jemaa, S., Bacha, M., Khalaf, G., Dessailly, D., Rabhi, K., and Amara, R. (2015). What can otolith shape analysis tell us about population structure of the European sardine, Sardina pilchardus, from Atlantic and Mediterranean waters? Journal of Sea Research 96, 11-17. doi:10.1016/ J.SEARES.2014.11.002

Kaouèche, M., Bahri-Sfar, L., Hammami, I., and Ben Hassine, O. K. (2017). Morphometric variantions in white seabream Diplodus sargus (Linneus, 1758) populations along the Tunisian coast. Oceanologia 59, 129-138. doi:10.1016/J.OCEANO.2016.10.003

Kasapidis, P., Silva, A., Zampicinini, G., and Magoulas, A. (2012). Evidence for microsatellite hitchhiking selection in European sardine (Sardina pilchardus) and implications in inferring stock structure. Scientia Marina 76, 123-132. doi:10.3989/SCIMAR.03366.29B

Kritzer, J. P., and Liu, O. R. (2013). Fishery management strategies for addressing complex spatial structure in marine fish stocks. In 'Stock Identification Methods: Applications in Fisheries Science'. 2nd Edn (Ed. S. X. Cadrin.) pp. 29-57. (Academic Press: USA.)

Kuhl, F. P., and Giardina, C. R. (1982). Elliptic Fourier features of a closed contour. Computer Graphics and Image Processing 18, 236-258. doi:10.1016/0146-664X(82)90034-X

Mapp, J., Hunter, E., Van Der Kooijc, J., Songer, S., and Fisher, M. (2017) Otolith shape and size: the importance of age when determining indices for fish-stock separation. Fisheries Research 190, 43-52. doi:10.1016 J.FISHRES.2017.01.017

Martins, M. M. (2007). Growth variability in Atlantic mackerel (Scomber scombrus) and Spanish mackerel (Scomber japonicus) off Portugal. ICES Journal of Marine Science 64, 1785-1790. doi:10.1093/ICESJMS/ FSM163

Martins, M. M., Skagen, D., Marques, V., Zwolinski, J., and Silva, A. (2013). Changes in the abundance and spatial distribution of the Atlantic chub mackerel (Scomber colias) in the pelagic ecosystem and fisheries off Portugal. Scientia Marina 77(4), 551-563. doi:10.3989/SCIMAR. 03861.07B

Mille, T., Ernande, B., Pontual, H., Villanueva, C., and Mahé, K. (2016). 'Sources of Otolith Morphology Variation at the Intra-population Level: Directional Asymmetry and Diet.' (SFI Days: Marseille, France.)

Moreira, C., Froufe, E., Sial, A. N., Caeiro, A., Vaz-Pires, P., and Correia, A. T. (2018). Population structure of the blue jack mackerel (Trachurus picturatus) in the NE Atlantic inferred from otolith microchemistry. Fisheries Research 197, 113-122. doi:10.1016/J.FISHRES.2017.08.012

Moreira, C., Froufe, E., Vaz-Pires, P., and Correia, A. T. (2019a). Otolith shape analysis as a tool to infer the population structure of the blue jack mackerel, Trachurus picturatus, in the NE Atlantic. Fisheries Research 209, 40-48. doi:10.1016/J.FISHRES.2018.09.010

Moreira, C., Correia, A. T., Vaz-Pires, P., and Froufe, E. (2019b). Genetic diversity and population structure of the blue jack mackerel Trachurus picturatus across its western distribution. Journal of Fish Biology 94, 725-731. doi:10.1111/JFB.13944

Nespereira, J. M. L., and Pajuelo, J. M. G. (1993). Determinación de la talla de primera madurez sexual y período reproductivo de la caballa (Scomber japonicus Houttuyn, 1782) de las islas Canarias. Boletín del Instituto Español de Oceanografía 9(1), 15-21 [in Spanish]

Panfili, J., Pontual, H., Troadec, H., and Wright, P. (2002). 'Manual of Sclerochronoly.' (IFREMER-IRD Coedition: Brest, France.)

Perrotta, R. G., Madirolas, A., Viñas, M. D., Akselman, R., Guerrero, R., Sánchez, F., López, F., Castro Machado, F., and Macchi, G. (1999). La caballa (Scomber japonicus) y las condiciones ambientales en el área bonaerense de 'El Rincón'. INIDEP Inf Téc. 26, 1-29. 
Reist, J. D. (1985). An empirical evaluation of several univariate methods that adjust for size variation in morphometric data. Canadian Journal of Zoology 63(6), 1429-1439. doi:10.1139/Z85-213

Rodgveller, C. J., Hutchinson, C. E., Harris, J. P., Vulstek, S. C., and Guthrie, C. M. (2017). Otolith shape variability and associated body growth differences in giant grenadier, Albatrossia pectoralis. PLoS One 12(6), e0180020. doi:10.1371/JOURNAL.PONE.0180020

Rohlf, F. J., and Slice, D. (1990). Extensions of the Procrustes method for the optimal superimposition of landmarks. Systematic Zoology 39, 40-59. doi: $10.2307 / 2992207$

Roldán, M. I., Perrotta, R. G., Cortey, M., and Pla, C. (2000). Molecular and morphologic approaches to discrimination of variability patterns in chub mackerel, Scomber japonicus. Journal of Experimental Marine Biology and Ecology 253, 63-74. doi:10.1016/S0022-0981(00)00244-6

Santos, A. M. P., Chícharo, A., Santos, A., Moita, T., Oliveira, P. B., Peliz, A., and Ré, P. (2007). Physical-biological interactions in the life history of small pelagic fish in the western Iberia upwelling ecosystem. Progress in Oceanography 74, 192-209. doi:10.1016/J.POCEAN.2007.04.008

Scoles, D. R., Collette, B. C., and Graves, J. E. (1998). Global phylogeography of mackerels of the genus Scomber. Fish Bulletin 96, 823-842.

Secor, D. H., Dean, J. M., and Laban, E. H. (1992). Otolith removal and preparation for microstructural examination. In 'Otolith Microstructure Examination and Analysis'. Canadian Special Publication of Fisheries and Aquatic Sciences 117. (Eds D. K. Stevenson and S. E. Campana.) pp. 19-57. (Communication Group - Publishing: Ottawa, Canada.)

Strauss, R. E., and Bookstein, F. L. (1982). The truss: body form reconstruction in morphometrics. Systematic Zoology 31(2), 113-135. doi:10. 2307/2413032

Tuset, V. M., Lozano, I. J., Gonzalez, J. A., Pertusa, J. F., and Garcia-Diaz, M. M. (2003). Shape indices to identify regional differences in otolith morphology of comber Serranus cabrilla (L., 1758). Journal of Applied Ichthyology 19, 88-93. doi:10.1046/J.1439-0426.2003.00344.X

Vasconcelos, J., Afonso-Dias, M., and Faria, G. (2012). Atlantic chub mackerel (Scomber colias) spawning season, size and age at first maturity in Madeira waters. Arquipélago. Ciências Biológicas e Marinhas 29, 43-51.

Vasconcelos, J., Vieira, A. R., Sequeira, V., González, J. A., Kaufmann, M., and Gordo, L. S. (2018). Identifying populations of the blue jack mackerel (Trachurus picturatus) in the Northeast Atlantic by using geometric morphometrics and otolith shape analysis. Fishery Bulletin 116, 81-92. doi:10.7755/FB.116.1.9

Vergara-Solana, F. J., García-Rodríguez, F. J., and Cruz-Agüero, D. L. (2013). Comparing body and otolith shape for stock discrimination of Pacific sardine, Sardinops sagax Jenyns, 1842. Journal of Applied Ichthyology 29, 1241-1246. doi:10.1111/JAI.12300

Vignon, M., and Morat, F. (2010). Environmental and genetic determinant of otolith shape revealed by non-indigenous tropical fish. Marine Ecology Progress Series 411, 231-241. doi:10.3354/MEPS08651

Villamor, B., Carrera, P., Castro, J., Ramos, F., Velasco, F., Sobrino, I., Navarro, M. R., Gancedo, R., Hernandez, C., Marín, M., Blanco, M., Tornero, J., and Burgos, C. (2017). 'The Chub Mackerel (Scomber colias) in the Atlantic Spanish Waters (ICES Divisions 8.c and 9.a): Biological, Fishery and Survey Data.' Working Document to WGWIDE. (Instituto Español de Oceanografia.)

Volpedo, A. V., and Vaz-dos-Santos, A. M. (2015). 'Métodos de Estudios con Otolitos: Principios y Aplicaciones/Métodos de Estudos con Otólitos: Princípios e Aplicações.' 1st edn. edición bilingue. (Ciudad Autónoma de Buenos Aires: Argentina.) [in Spanish]

Zardoya, R., Castilho, R., Grande, C., Favre-Krey, L., Caetano, S., Marcato, S., Krey, G., and Paternello, T. (2004). Differential population structuring of two closely related fish species, the mackerel (Scomber scombrus) and the chub mackerel (Scomber japonicus), in the Mediterranean Sea. Molecular Ecology 13, 1785-1798. doi:10.1111/J.1365-294X.2004. 02198.X

Handling Editor: Michael Kingsford 